\title{
Wheat Production under Long-term Application of Inorganic and Organic Fertilizers in Rice-Wheat System under Rainfed Conditions
}

\author{
Suresh K. Rai and Yajna G. Khadka \\ Soil Science Division, NARC, Khumaltar, Lalitpur, Nepal
}

\begin{abstract}
Under rainfed rice-wheat cropping system, experiments were conducted on wheat variety Annapurna-2 from 1998 to 2002 to study the effect of continuous application of inorganic and organic fertilizers in longer run on wheat production and soil properties in alluvial soil of Khumaltar, Lalitpur at 1365 msal. Eleven different fertilizers combinations comprised of inorganic and organic fertilizers were used. The results of the five-year experiment indicate that the applications of optimal level of inorganic fertilizers could supply the plant nutrients to wheat crop to produce sustainable yield. On the other hand, organic fertilizers could help to increase the crop yield and maintain soil fertility at the same time. Residual effect of available phosphorus applied in previous rice crop had significant response on wheat yield. For maintaining soil fertility, application of FYM and incorporation of crop residue into soil are worth practicable.
\end{abstract}

Key words: Inorganic and organic fertilizers, rice-wheat cropping system, wheat crop

Wheat is one of the important winter crops in Nepal, which contributes $18 \%$ of its share in total cereal production and 39\% (MoAC 2005) in total GDP from agriculture. As with the saying that wheat is grown by fertilizers, farmers in Nepal prefer growing wheat with more inorganic (Bhattarai and Mishra 1998) and with some organic fertilizers than the rice crop.

With the increasing population every year, the pressure for increasing food production has also increased to feed the increasing population. This has compelled people to introduce high yielding crop varieties. With the introduction of such high yielding crop varieties, the use of chemical fertilizers have also been increased. The application of inorganic fertilizers however, are not judicious or as per recommendation (Maskey et al 2000). Continuous application of acidifying fertilizers for long period; especially ammonium sulphate and urea have turned the soil into acidic conditions which in turn have affected on the unavailability of nutrients to crops other than degrading soil health and environment, too.

In the hill agriculture, application of FYM is a common practice. Quality FYM helps improve physico-chemical properties of soil and makes soil nutrients available to plants gradually for longer period. Inorganic fertilizers while in combination with organic fertilizers help improve soil health and sustain crop yield. For better crop production, combinations of both play important role. Fertilizer use, though has been a prime contributing factor for the increased agricultural productivity 
in these areas, there are situations when they are not available in right time and adequate quantity despite high priced. Additionally, there is a risk of environmental hazards due to their imbalanced application resulting into declined soil fertility, crop productivity, and environmental instability. On the other hand, inadequate plant nutrients supply has been considered as one of the factors of lower crop productivity.

The long-term effects of using inorganic fertilizers are of great significance in relation to sustain the crop yield, maintain soil fertility and protect the environment as well. For a resource poor country like Nepal, the use of fertilizer alone may not be a viable solution to sustain the crop yield and maintain soil health under rice-wheat system; the predominant cropping system. In order to study these effects, experiments on the use of inorganic fertilizers and organic manure on wheat production under rice-wheat system were initiated in 1980/81 in various locations of the country. This study is also a part of the experiment. This experiment in particular has been started in 1993 at Khumaltar with the objective of studying the effect of long-term application of chemical and organic fertilizers on the wheat yield and soil properties.

\section{MATERIALS AND METHODS}

The experiment was laid out in a randomized complete block design (RCBD) as described by Gomez and Gomez (1984) with eleven treatments replicated four times. The details of the treatments are given in Table 1. Since the experiment was in rice-wheat cropping system, the fertilizer details of the rice season are also shown in the table. The size of each plot was $4-\times 3-\mathrm{m}$. Nitrogen, phosphorus and potash was supplied through di-ammonium phosphate, urea and muriate of potash, respectively. Full dose of phosphorus and potash and half dose of nitrogen were applied at the time of sowing. Full dose of organic manure was applied at the time of final land preparation. The seeds of wheat variety Annapurna- 2 were sown in rows with spacing of $20 \mathrm{~cm}$. The remaining half dose of nitrogen was top dressed at crown-root-initiation stage. Yield and yield attributing parameters; tiller number, panicle number, length, plant height, 1000-grain weight were recorded. Composite soil samples were taken after each crop harvest for chemical analysis. Statistical analysis was done in IRRISTAT (2005).

Table 1. Treatment details of the experiment

\begin{tabular}{lll}
\hline \multirow{2}{*}{$\begin{array}{c}\text { Treatment } \\
\text { no. }\end{array}$} & \multicolumn{2}{c}{ Treatment details } \\
\cline { 2 - 3 } 1 & $0: 0: 0($ Control $)$ & Rice $\left(\mathrm{N}_{2} \mathrm{P}_{2} \mathrm{O}_{5}: \mathrm{K}_{2} \mathrm{O}, \mathrm{kg} \mathrm{ha}^{-1}\right)$ \\
2 & $100: 0: 0$ & $0: 0: 0(\mathrm{Control})$ \\
3 & $100: 40: 0$ & $100: 0: 0$ \\
4 & $100: 0: 30$ & $100: 40: 00$ \\
5 & $100: 40: 30$ & $100: 0: 30$ \\
6 & $100: 40: 30$ & $100: 40: 30$ \\
7 & $100: 40: 30$ & $100: 40: 30$ \\
8 & $\left.50: 0: 0+15 \mathrm{~cm}_{2} \mathrm{O}, \mathrm{kg} \mathrm{ha}^{-1}\right)$ \\
9 & $50: 20: 0$ & $100: 40: 30$ \\
10 & $\mathrm{FYM} 10$ tons ha ${ }^{-1}$ & $50: 0: 0+15 \mathrm{~cm}$ wheat straw \\
11 & $100: 40: 30$ & $50: 20: 0$ \\
\hline
\end{tabular}




\section{RESULTS AND DISCUSSION}

\section{Yield and yield components}

Tiller number: Treatment effects were not significant for tiller number per square meter almost in all of the year except $1999(\mathrm{p}=0.003)$ (Table 2). Combined analysis over the years showed a significant effects $(\mathrm{P}<0.000)$ while treatment effect was insignificant. The highest tiller per meter square of 352 was recorded from treatment $6\left(100: 40: 30 \mathrm{~N}: \mathrm{P}_{2} \mathrm{O}_{5}: \mathrm{K}_{2} \mathrm{O} \mathrm{kg} \mathrm{ha}{ }^{-1}\right)$ and 7 (100:40:30 $\left.\mathrm{N}: \mathrm{P}_{2} \mathrm{O}_{5}: \mathrm{K}_{2} \mathrm{O} \mathrm{kg} \mathrm{ha}^{-1}\right)$ followed by treatment $11\left(100: 40: 30 \mathrm{~N}: \mathrm{P}_{2} \mathrm{O}_{5}: \mathrm{K}_{2} \mathrm{O} \mathrm{kg} \mathrm{ha}{ }^{-1}\right)$ with the mean of 350. Variation over the years is quite distinct which was mainly due to variation in climatic conditions.

Table 2. Effect on tiller numbers of wheat crop with application of inorganic fertilizers and organic manure

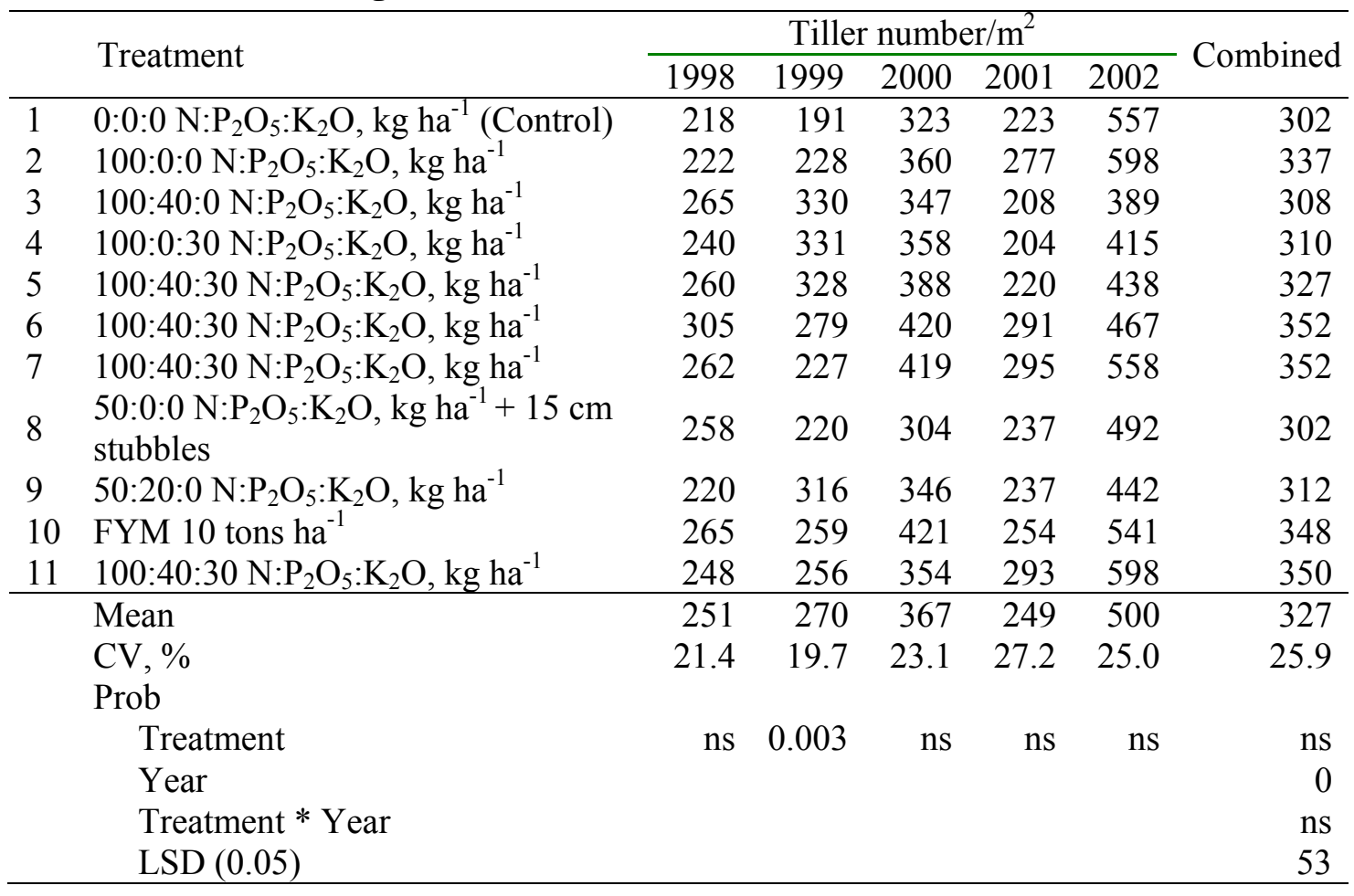

Plant height: Plant heights in different years were not affected significantly by treatments (Table 3 ). On combined analysis, the treatment effects were significant $(\mathrm{p}=0.000)$. The response due to year was also significant $(\mathrm{p}=0.000)$. The highest plant height of $89 \mathrm{~cm}$ was recorded from the treatment $6\left(100: 40: 30 \mathrm{~N}: \mathrm{P}_{2} \mathrm{O}_{5}: \mathrm{K}_{2} \mathrm{O} \mathrm{kg} \mathrm{ha}{ }^{-1}\right)$. Most of the treatment effects were at par except the treatment 1 (Control), which produced the least mean plant height of $78.8 \mathrm{~cm}$. Over the years, the highest plant height of $111.6 \mathrm{~cm}$ was recorded from the treatment $10\left(\mathrm{FYM} 10\right.$ tons ha $\left.\mathrm{h}^{-1}\right)$. Interaction between treatment and year was significant $(\mathrm{p}=0.04)$.

Panicle length: Except 1998 and 2001, the panicle length analysis showed a significant response (p $<0.00$ ) over the years (Table 4). However, in the year 2002, the highest panicle length of $8.3 \mathrm{~cm}$ was recorded from the treatment $11\left(100: 40: 30 \mathrm{~N}: \mathrm{P}_{2} \mathrm{O}_{5}: \mathrm{K}_{2} \mathrm{O} \mathrm{kg} \mathrm{ha}^{-1}\right)$ which had soybean green manure incorporated into the soil previous season. The combined analysis over the years showed significant result $(\mathrm{p}=0.000)$. Treatment $6\left(100: 40: 30 \mathrm{~N}: \mathrm{P}_{2} \mathrm{O}_{5}: \mathrm{K}_{2} \mathrm{O} \mathrm{kg} \mathrm{ha}{ }^{-1}\right)$ produced the highest 
mean panicle length of $10 \mathrm{~cm}$ which was at par with treatment $5\left(100: 40: 30 \mathrm{~N}: \mathrm{P}_{2} \mathrm{O}_{5}: \mathrm{K}_{2} \mathrm{O} \mathrm{kg} \mathrm{ha}{ }^{-1}\right)$. Panicle length was significantly affected by the recommended dose of the inorganic fertilizers.

Grain yield: The treatment response on grain yield was insignificant in most of the years except in $2000(\mathrm{P}=0.002)$ (Table 5). On combined analysis, the response was significant $(\mathrm{P}=0.004)$. The highest mean grain yield of $2929 \mathrm{~kg} \mathrm{ha}^{-1}$ was recorded from the recommended dose of NPK ie treatment $5\left(100: 40: 30 \mathrm{~N}: \mathrm{P}_{2} \mathrm{O}_{5}: \mathrm{K}_{2} \mathrm{O} \mathrm{kg} \mathrm{ha}{ }^{-1}\right)$ indicating the better response of wheat to applied nutrients through inorganic source. The balanced application of nutrients has its incremental effects on wheat grain yield. Similar findings have also been reported from the long-term fertility

Table 3. Effect on plant height $(\mathrm{cm})$ of wheat crop with application of inorganic fertilizers and organic manure

\begin{tabular}{|c|c|c|c|c|c|c|}
\hline \multirow{2}{*}{ Treatment } & \multicolumn{5}{|c|}{ Plant height, $\mathrm{cm}$} & \\
\hline & 1998 & 1999 & 2000 & 2001 & 2002 & nbined \\
\hline $10: 0: 0 \mathrm{~N}: \mathrm{P}_{2} \mathrm{O}_{5}: \mathrm{K}_{2} \mathrm{O}, \mathrm{kg} \mathrm{ha}^{-1}$ (Control) & 104.3 & 67.5 & 80.6 & 64.4 & 77.0 & $\overline{78.8}$ \\
\hline 2 100:0:0 N: $\mathrm{P}_{2} \mathrm{O}_{5}: \mathrm{K}_{2} \mathrm{O}, \mathrm{kg} \mathrm{ha}^{-1}$ & 106.5 & 79.1 & 86.3 & 71.2 & 90.3 & 86.7 \\
\hline 3 100:40:0 N: $\mathrm{P}_{2} \mathrm{O}_{5}: \mathrm{K}_{2} \mathrm{O}, \mathrm{kg} \mathrm{ha}^{-1}$ & 107.0 & 81.9 & 87.1 & 70.5 & 81.8 & 85.7 \\
\hline 4 100:0:30 N: $\mathrm{P}_{2} \mathrm{O}_{5}: \mathrm{K}_{2} \mathrm{O}, \mathrm{kg} \mathrm{ha}^{-1}$ & 109.1 & 84.1 & 90.6 & 67.9 & 84.5 & 87.2 \\
\hline $5 \quad 100: 40: 30 \mathrm{~N}: \mathrm{P}_{2} \mathrm{O}_{5}: \mathrm{K}_{2} \mathrm{O}, \mathrm{kg} \mathrm{ha}^{-1}$ & 111.2 & 85.8 & 90.2 & 69.4 & 81.8 & 87.7 \\
\hline $6 \quad 100: 40: 30 \mathrm{~N}: \mathrm{P}_{2} \mathrm{O}_{5}: \mathrm{K}_{2} \mathrm{O}, \mathrm{kg} \mathrm{ha}^{-1}$ & 107.1 & 87.4 & 97.3 & 70.4 & 83.0 & 89.0 \\
\hline $7 \quad 100: 40: 30 \mathrm{~N}: \mathrm{P}_{2} \mathrm{O}_{5}: \mathrm{K}_{2} \mathrm{O}, \mathrm{kg} \mathrm{ha}^{-1}$ & 110.9 & 87.3 & 93.7 & 68.8 & 81.3 & 88.4 \\
\hline $850: 0: 0 \mathrm{~N}: \mathrm{P}_{2} \mathrm{O}_{5}: \mathrm{K}_{2} \mathrm{O}, \mathrm{kg} \mathrm{ha}^{-1}+15 \mathrm{~cm}$ stubbles & 106.5 & 76.4 & 86.3 & 77.1 & 70.5 & 83.4 \\
\hline $950: 20: 0 \mathrm{~N}: \mathrm{P}_{2} \mathrm{O}_{5}: \mathrm{K}_{2} \mathrm{O}, \mathrm{kg} \mathrm{ha}^{-1}$ & 106.8 & 75.9 & 87.2 & 75.3 & 77.5 & 84.5 \\
\hline $10 \mathrm{FYM}_{10}$ tons $\mathrm{ha}^{-1}$ & 111.6 & 75.2 & 88.9 & 75.3 & 76.0 & 85.4 \\
\hline $11100: 40: 30 \mathrm{~N}: \mathrm{P}_{2} \mathrm{O}_{5}: \mathrm{K}_{2} \mathrm{O}, \mathrm{kg} \mathrm{ha}^{-1}$ & 104.4 & 85.5 & 90.2 & 65.2 & 85.0 & 86.0 \\
\hline Mean & 107.7 & 80.6 & 88.9 & 70.5 & 80.8 & 85.7 \\
\hline $\mathrm{CV}, \%$ & 3.05 & 3.83 & 7.29 & 10.10 & 11.85 & 7.98 \\
\hline Prob & & & & & & \\
\hline Treatment & 0.028 & 0.000 & ns & $\mathrm{ns}$ & ns & 0.000 \\
\hline Year & & & & & & 0.000 \\
\hline Treatment $*$ Year & & & & & & 0.044 \\
\hline LSD $(0.05)$ & & & & & & 4.27 \\
\hline
\end{tabular}

Table 4. Effect on panicle length of wheat crop with application of inorganic fertilizers and organic manure

\begin{tabular}{llcccccr}
\hline \multirow{2}{*}{ Treatment } & \multicolumn{5}{c}{ Panicle length, cm } & \multirow{2}{*}{ Combined } \\
\cline { 3 - 7 } & & 1998 & 1999 & 2000 & 2001 & 2002 & \\
\hline 1 & $0: 0: 0 \mathrm{~N}: \mathrm{P}_{2} \mathrm{O}_{5}: \mathrm{K}_{2} \mathrm{O}, \mathrm{kg} \mathrm{ha}^{-1}(\mathrm{Control})$ & 14.9 & 7.1 & 3.4 & 11.3 & 6.0 & 8.5 \\
2 & $100: 0: 0 \mathrm{~N}: \mathrm{P}_{2} \mathrm{O}_{5}: \mathrm{K}_{2} \mathrm{O}, \mathrm{kg} \mathrm{ha}^{-1}$ & 15.4 & 8.7 & 3.7 & 12.0 & 7.3 & 9.4 \\
3 & $100: 40: 0 \mathrm{~N}: \mathrm{P}_{2} \mathrm{O}_{5}: \mathrm{K}_{2} \mathrm{O}, \mathrm{kg} \mathrm{ha}^{-1}$ & 15.9 & 8.8 & 4.4 & 12.6 & 7.5 & 9.8 \\
4 & $100: 0: 30 \mathrm{~N}: \mathrm{P}_{2} \mathrm{O}_{5}: \mathrm{K}_{2} \mathrm{O}, \mathrm{kg} \mathrm{ha}^{-1}$ & 15.4 & 8.9 & 5.0 & 11.7 & 7.8 & 9.7 \\
5 & $100: 40: 30 \mathrm{~N}: \mathrm{P}_{2} \mathrm{O}_{5}: \mathrm{K}_{2} \mathrm{O}, \mathrm{kg} \mathrm{ha}^{-1}$ & 15.8 & 8.6 & 5.1 & 12.7 & 7.8 & 9.9 \\
6 & $100: 40: 30 \mathrm{~N}: \mathrm{P}_{2} \mathrm{O}_{5}: \mathrm{K}_{2} \mathrm{O}, \mathrm{kg} \mathrm{ha}^{-1}$ & 16.8 & 8.4 & 5.5 & 12.1 & 7.3 & 10.0 \\
7 & $100: 40: 30 \mathrm{~N}: \mathrm{P}_{2} \mathrm{O}_{5}: \mathrm{K}_{2} \mathrm{O}, \mathrm{kg} \mathrm{ha}^{-1}$ & 16.2 & 9.0 & 4.2 & 11.6 & 7.8 & 9.8 \\
& $50: 0: 0 \mathrm{~N}: \mathrm{P}_{2} \mathrm{O}_{5}: \mathrm{K}_{2} \mathrm{O}, \mathrm{kg} \mathrm{ha}^{-1}+15 \mathrm{~cm}$ & 15.4 & 6.9 & 3.0 & 12.4 & 6.8 & 8.9 \\
& stubbles & & & & & &
\end{tabular}




\begin{tabular}{|c|c|c|c|c|c|c|}
\hline \multirow{2}{*}{ Treatment } & \multicolumn{5}{|c|}{ Panicle length, $\mathrm{cm}$} & \multirow{2}{*}{ Combined } \\
\hline & 1998 & 1999 & 2000 & 2001 & 2002 & \\
\hline $9 \quad 50: 20: 0 \mathrm{~N}: \mathrm{P}_{2} \mathrm{O}_{5}: \mathrm{K}_{2} \mathrm{O}, \mathrm{kg} \mathrm{ha}^{-1}$ & 15.2 & 7.8 & 4.4 & 12.7 & 7.5 & 9.5 \\
\hline 10 FYM 10 tons $\mathrm{ha}^{-1}$ & 15.8 & 7.3 & 4.3 & 11.8 & 6.3 & 9.1 \\
\hline 11 100:40:30 N: $\mathrm{P}_{2} \mathrm{O}_{5}: \mathrm{K}_{2} \mathrm{O}, \mathrm{kg} \mathrm{ha}^{-1}$ & 15.5 & 7.6 & 3.8 & 11.5 & 8.3 & 9.3 \\
\hline Mean & 15.7 & 8.1 & 4.3 & 12.0 & 7.3 & 9.5 \\
\hline $\mathrm{CV}, \%$ & 4.63 & 7.39 & 17.89 & 6.41 & 9.21 & 8.55 \\
\hline Prob & & & & & & \\
\hline Treatment & ns & 0.000 & 0.002 & ns & 0.001 & 0.000 \\
\hline Year & & & & & & 0.000 \\
\hline Treatment $*$ Year & & & & & & 0.025 \\
\hline $\operatorname{LSD}(0.05)$ & & & & & & 0.505 \\
\hline
\end{tabular}

experiments in Parwanipur and Tarahara (Yadav et al 1998). Increment in the wheat grain yield could be due to application of phosphorus that might have been available from the phosphorus applied in previous rice crop. The effects of phosphorus in wheat grain yield have also been reported by Yadav et al (1998), Bhattarai and Mishra (1998) and Regmi (1998). Finding of Brar et al 1998 also confirms the significant response of $\mathrm{P}$ on wheat production.

Table 5. Effect on grain yield of Annapurna 2 wheat crop with application of inorganic fertilizers and organic manure

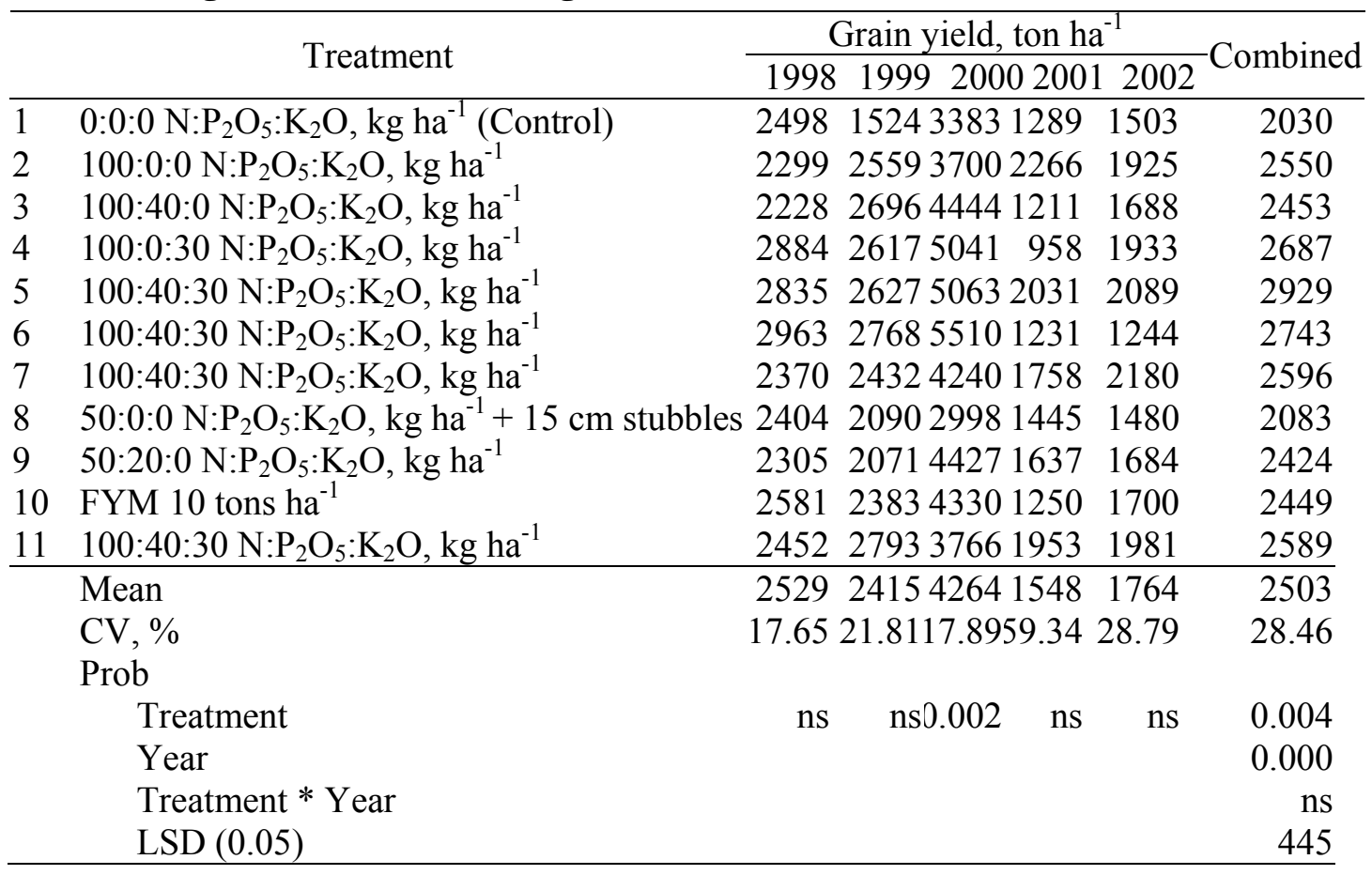

The effect of the application of FYM @ of 10 tons ha-1 (treatment 10) was also encouraging (2449 $\mathrm{kg} \mathrm{ha}^{-1}$ ). The lower yield from treatment 10 was possibly due to low mineralization rate as affected by lower temperature and moisture condition during crop growth period (Bhattarai and Mishra 1998, 
Tripathi and Suwal 1999 and Pandey et al 1998). Residual effect of soybean was observed on wheat yield on combined analysis.

Straw yield: The response of the treatment was significant $(\mathrm{P}<0.05)$ except in the years 1998 and 2001 (Table 6). Treatment responses were varied over the years. However, in the combined analysis over the years, the highest straw yield was obtained from the treatment $5\left(100: 40: 30 \mathrm{~N}: \mathrm{P}_{2} \mathrm{O}_{5}: \mathrm{K}_{2} \mathrm{O} \mathrm{kg}\right.$ $\mathrm{ha}^{-1}$ ) followed by treatment 7. Similar findings have been reported by Bhattarai and Mishra (1998). It could have been due to higher nitrogen application in the treatment. Straw yields are higher in the treatments with recommended dose of fertilizers. Like in grain yield, wheat straw yield was significantly higher in the treatments where green manure was applied in rice season and recommended dose of fertilizer was applied in wheat indicating the sufficient supply of the nutrients to crop.

\section{Effects on soil properties}

Nitrogen: Variations in soil nitrogen due to various treatments were insignificant in combined analysis of the data over the years. However, there were increments in soil nitrogen in every treatment at the end of the five years. Similar findings have been reported by Bhattarai and Mishra (1998). Higher nitrogen percent in treatment 10 (Table 7) could possibly due to increasing soil humus content through continuous application of organic fertilizer (Larson and Clapp 1984).

Available phosphorus: On combined analysis, the treatment effects were insignificant. Variation due to years on available soil phosphorus was significant (Table 7). Treatment 11 (100:40:30 $\left.\mathrm{N}: \mathrm{P}_{2} \mathrm{O}_{5}: \mathrm{K}_{2} \mathrm{O} \mathrm{kg} \mathrm{ha}{ }^{-1}\right)$ had the highest available phosphorus $\left(127.77 \mathrm{~kg} \mathrm{ha}^{-1}\right)$ which could have been resulted due to the residual effect of the soybean incorporated in the rice season. Gami and Sah (1998) also reported similar finding in the long-term experiment. Considerable amount of available P was build up with all rates of $\mathrm{P}$ application confirming with the result of Brar and Pasricha 1998.

Table 6. Effect on straw yield of wheat crop with application of inorganic fertilizers and organic manure

\begin{tabular}{|c|c|c|c|c|c|c|}
\hline \multirow{2}{*}{ Treatment } & \multicolumn{5}{|c|}{ Straw yield, ton $\mathrm{ha}^{-1}$} & \multirow{2}{*}{ mbined } \\
\hline & 1998 & 1999 & 2000 & 2001 & 2002 & \\
\hline $10: 0: 0 \mathrm{~N}: \mathrm{P}_{2} \mathrm{O}_{5}: \mathrm{K}_{2} \mathrm{O}, \mathrm{kg} \mathrm{ha}^{-1}$ (Control) & 2051 & 2168 & 4024 & 2188 & 2236 & 2533 \\
\hline $2100: 0: 0 \mathrm{~N}: \mathrm{P}_{2} \mathrm{O}_{5}: \mathrm{K}_{2} \mathrm{O}, \mathrm{kg} \mathrm{ha}^{-1}$ & 1739 & 2676 & 5664 & 4395 & 3596 & 3614 \\
\hline 3 100:40:0 N: $\mathrm{P}_{2} \mathrm{O}_{5}: \mathrm{K}_{2} \mathrm{O}, \mathrm{kg} \mathrm{ha}^{-1}$ & 1725 & 2950 & 7207 & 2461 & 2088 & 3286 \\
\hline $4100: 0: 30 \mathrm{~N}: \mathrm{P}_{2} \mathrm{O}_{5}: \mathrm{K}_{2} \mathrm{O}, \mathrm{kg} \mathrm{ha}^{-1}$ & 2250 & 3301 & 7331 & 2324 & 2813 & 3604 \\
\hline $5 \quad 100: 40: 30 \mathrm{~N}: \mathrm{P}_{2} \mathrm{O}_{5}: \mathrm{K}_{2} \mathrm{O}, \mathrm{kg} \mathrm{ha}^{-1}$ & 2182 & 3438 & 6992 & 4961 & 2479 & 4010 \\
\hline $6 \quad 100: 40: 30 \mathrm{~N}: \mathrm{P}_{2} \mathrm{O}_{5}: \mathrm{K}_{2} \mathrm{O}, \mathrm{kg} \mathrm{ha}^{-1}$ & 2446 & 2988 & 7852 & 2988 & 2446 & 3744 \\
\hline $7 \quad 100: 40: 30 \mathrm{~N}: \mathrm{P}_{2} \mathrm{O}_{5}: \mathrm{K}_{2} \mathrm{O}, \mathrm{kg} \mathrm{ha}^{-1}$ & 1810 & 2735 & 7286 & 4687 & 3280 & 3959 \\
\hline $850: 0: 0 \mathrm{~N}: \mathrm{P}_{2} \mathrm{O}_{5}: \mathrm{K}_{2} \mathrm{O}, \mathrm{kg} \mathrm{ha}^{-1}+15 \mathrm{~cm}$ stubbles & 1651 & 1612 & 3926 & 3086 & 2722 & 2599 \\
\hline 9 50:20:0 N: $\mathrm{P}_{2} \mathrm{O}_{5}: \mathrm{K}_{2} \mathrm{O}, \mathrm{kg} \mathrm{ha}^{-1}$ & 1795 & 2305 & 6387 & 2598 & 3081 & 3233 \\
\hline 10FYM 10 tons $\mathrm{ha}^{-1}$ & 2188 & 2559 & 5156 & 3203 & 3480 & 3317 \\
\hline $11100: 40: 30 \mathrm{~N}: \mathrm{P}_{2} \mathrm{O}_{5}: \mathrm{K}_{2} \mathrm{O}, \mathrm{kg} \mathrm{ha}^{-1}$ & 1960 & 2305 & 7442 & 3360 & 3539 & 3721 \\
\hline Mean & 1982 & 2640 & 6297 & 3296 & 2887 & 3420 \\
\hline $\mathrm{CV}, \%$ & 21.7 & 24.75 & 28.48 & 61.26 & 24.13 & 39.14 \\
\hline \multicolumn{7}{|l|}{ Prob } \\
\hline Treatment & ns & 0.019 & 0.029 & ns & 0.031 & 0.004 \\
\hline Year & & & & & & 0.000 \\
\hline Treatment $*$ Year & & & & & & $\mathrm{ns}$ \\
\hline LSD $(0.05)$ & & & & & & 836 \\
\hline
\end{tabular}


However, addition of straw to $50 \mathrm{~kg} \mathrm{~N} \mathrm{ha}{ }^{-1}$ could not increase the available phosphorus in soil (Treatment 8). The second highest available phosphorus in soil was recorded in treatment 5 followed by treatment 6 in which recommended dose of phosphorus was applied continuously. The lowest available soil phosphorus $(52.55 \mathrm{~kg}$ ha-1) was recorded in treatment with no nutrient at all. Treatments with application of lower amounts of phosphorus had also lower available phosphorus in soil.

Table 7. Combined mean of five years data on soil properties (1998-2002)

\begin{tabular}{|c|c|c|c|c|c|}
\hline \multicolumn{2}{|r|}{ Treatment } & $\mathrm{N}, \%$ & $\mathrm{Av} \mathrm{P}_{2} \mathrm{O}_{5}, \mathrm{~kg} \mathrm{ha}^{-1}$ & $\mathrm{Av} \mathrm{K}_{2} \mathrm{O}, \mathrm{kg} \mathrm{ha}^{-1}$ & OM, \% \\
\hline 1 & 0:0:0 N: $\mathrm{P}_{2} \mathrm{O}_{5}: \mathrm{K}_{2} \mathrm{O}, \mathrm{kg} \mathrm{ha}^{-1}$ (Control) & 0.106 & 2.55 & 152.75 & 1.68 \\
\hline 2 & $100: 0: 0 \mathrm{~N}: \mathrm{P}_{2} \mathrm{O}_{5}: \mathrm{K}_{2} \mathrm{O}, \mathrm{kg} \mathrm{ha}^{-1}$ & 0.162 & 83.03 & 175.50 & 1.96 \\
\hline 3 & $100: 40: 0 \mathrm{~N}: \mathrm{P}_{2} \mathrm{O}_{5}: \mathrm{K}_{2} \mathrm{O}, \mathrm{kg} \mathrm{ha}^{-1}$ & 0.165 & 109.38 & 187.00 & 2.28 \\
\hline 4 & $100: 0: 30 \mathrm{~N}: \mathrm{P}_{2} \mathrm{O}_{5}: \mathrm{K}_{2} \mathrm{O}, \mathrm{kg} \mathrm{ha}^{-1}$ & 0.169 & 108.12 & 193.70 & 2.97 \\
\hline 5 & $100: 40: 30 \mathrm{~N}: \mathrm{P}_{2} \mathrm{O}_{5}: \mathrm{K}_{2} \mathrm{O}, \mathrm{kg} \mathrm{ha}^{-1}$ & 0.183 & 117.45 & 193.50 & 3.52 \\
\hline 6 & $100: 40: 30 \mathrm{~N}: \mathrm{P}_{2} \mathrm{O}_{5}: \mathrm{K}_{2} \mathrm{O}, \mathrm{kg} \mathrm{ha}^{-1}$ & 0.166 & 116.45 & 205.95 & 3.44 \\
\hline 7 & $100: 40: 30 \mathrm{~N}: \mathrm{P}_{2} \mathrm{O}_{5}: \mathrm{K}_{2} \mathrm{O}, \mathrm{kg} \mathrm{ha}^{-1}$ & 0.173 & 112.49 & 191.20 & 3.32 \\
\hline 8 & $\begin{array}{l}\text { 50:0:0 N:P }{ }_{2} \mathrm{O}_{5}: \mathrm{K}_{2} \mathrm{O}, \mathrm{kg} \mathrm{ha}^{-1}+15 \mathrm{~cm} \\
\text { stubbles }\end{array}$ & 0.165 & 81.66 & 190.50 & 3.66 \\
\hline 9 & $50: 20: 0 \mathrm{~N}: \mathrm{P}_{2} \mathrm{O}_{5}: \mathrm{K}_{2} \mathrm{O}, \mathrm{kg} \mathrm{ha}^{-1}$ & 0.154 & 79.75 & 182.95 & 3.45 \\
\hline $\begin{array}{l}1 \\
0\end{array}$ & FYM 10 tons ha $^{-1}$ & 0.172 & 67.73 & 162.75 & 3.97 \\
\hline $\begin{array}{l}1 \\
1\end{array}$ & $100: 40: 30 \mathrm{~N}: \mathrm{P}_{2} \mathrm{O}_{5}: \mathrm{K}_{2} \mathrm{O}, \mathrm{kg} \mathrm{ha}^{-1}$ & 0.162 & 126.77 & 185.85 & 2.46 \\
\hline & Mean & 0.162 & 95.90 & 183.79 & 2.97 \\
\hline & F-test & & & & \\
\hline & Treatment & $\mathrm{ns}$ & ns & ns & 0 \\
\hline & Year & 0 & 0 & 0 & 0 \\
\hline & $\mathrm{T}^{*} \mathrm{Y}$ & $\mathrm{ns}$ & ns & ns & ns \\
\hline
\end{tabular}

Available potassium: Treatments were insignificant on combined analysis of all five years' data. The effect of the year on available potassium was significant which might be due to climatic variations over the years. Treatment $6\left(100: 40: 30 \mathrm{~N}: \mathrm{P}_{2} \mathrm{O}_{5}: \mathrm{K}_{2} \mathrm{O} \mathrm{kg} \mathrm{ha}{ }^{-1}\right)$ produced the highest amount of available potassium in the soil $\left(205.95 \mathrm{~kg} \mathrm{ha}^{-1}\right)$ followed by treatment $4\left(193.7 \mathrm{~kg} \mathrm{ha}^{-1}\right)$ having 100:0:30 N: $\mathrm{P}_{2} \mathrm{O}_{5}: \mathrm{K}_{2} \mathrm{O} \mathrm{kg} \mathrm{ha}{ }^{-1}$ application. The least available potassium $152.75 \mathrm{~kg} \mathrm{ha}^{-1}$ was recorded in treatment 1 (control).

Organic matter: The highest soil organic matter was recorded in treatment 10 which had continuous supply of FYM @ 10 ton ha $^{-1}$ (Table 7) followed by treatment 8 in which $15 \mathrm{~cm}$ of rice straw (stubbles) was incorporated into the soil along with 50:0:0 N: $\mathrm{P}_{2} \mathrm{O}_{5}: \mathrm{K}_{2} \mathrm{O} \mathrm{kg} \mathrm{ha}{ }^{-1}$. Gami and Sah (1998) have also reported the increment of organic matter in soil when FYM and chopped straw was applied in the soil. Soil organic matter content, in general was high in almost all treatments having high phosphorus or FYM application. It could be due to high amount of root and stubbles incorporated into the soil (Regmi 1998). Treatment effects of soil organic matter content were highly significant and the effect over the years was significant. 


\section{CONCLUSION}

The result of this long-term experiment under rice-wheat cropping system demonstrated that the sustainable wheat production could be possible through inorganic fertilizers application with optimal level of NPK and high yielding variety under rice-wheat system in rainfed conditions. Single application of nitrogenous fertilizers or organic manures could not supplement the nutrients in sufficient amount required by the wheat crop for sustainable production under rainfed conditions. Further study should be continued focusing more on the use of the combination of inorganic and organic manure in various ratio in order to identify the best combination that would result into sustainable production along with better soil fertility and environment-friendly conditions.

\section{REFERENCES}

Bhattarai EM and R Mishra. 1998. Effect of long term application of chemical fertilizer and manure on crop production and soil fertility under rice-wheat cropping pattern at Khajura, Nepalgunj. In: Proceedings of first national workshop on long-term soil fertility experiments (SL Maskey, BP Tripathi, AP Regmi, JK Tuladhar and B Adhikary, eds). Soil Science Division, Nepal Agricultural Research Council, CIMMYT/HARP, Khumaltar, Nepal. Pp. 59-84.

Brar BS, Y Singh, NS Dhillon and B Singh. 1998. Long term effects of inorganic fertilizers, organic manures and crop residues on the productivity and sustainability of a ricewheat cropping system in North-West India. In: Long-term soil fertility management through integrated plant nutrient supply (A Swarup, DD Raddy and RN Prasad, eds). Indian Institute of Soil Science, Bhopal, India. Pp. 169-182.

Brar BS and NS Pasricha. 1998. Long-term studies on integraed use of organic and inorganic fertilizers in maize-wheat-cowpea cropping system on alluvial soil of Punjab. In: Long-term soil fertility management through integrated plant nutrient supply (A Swarup, DD Raddy and RN Prasad, eds). Indian Institute of Soil Science, Bhopal, India. Pp. 154-168.

Gomez KA and AA Gomez. 1984. Statistical procedures for agricultural research. $2^{\text {nd }}$ Edition. John Willy and Sons, New York. 680 pp.

IRRISTAT. 2005. IRRISTAT for Windows. Ver. 5.0. International Rice Research Institute, Manila, Philippines.

Maskey SL, RK Shrestha, B Shrestha, BP Tripathi, RC Munankarmy, YG Khadka, EM Bhattarai and SP Shrestha. 2000. Strategies for soil fertility research in the hills of Nepal. Soil Science Division, NARC, Khumaltar, Lalitpur, Nepal, 162 pp.

Regmi AP. 1998. Long-term soil fertility experiment on the rice-rice-wheat system at Bhairahawa. In: Proceedings of first national workshop on long-term soil fertility experiments (SL Maskey, BP Tripathi, AP Regmi, JK Tuladhar and B Adhikary, eds). Soil Science Division, Nepal Agricultural Research Council, CIMMYT/HARP, Khumaltar, Nepal. Pp. 95-115.

MoAC. 2005. Statistical information on Nepalese Agriculture. Agri-Business Promotio and Statistics Division, Agri Statistics Section, Ministry of Agriculture and Cooperatives (MoAC), His Majesty's Government, Singha Durbar, Kathmandu, Nepal. 
Larson WE and CE Clapp. 1984. Effects of organic matter on soil physical properties. Organic matter and rice. IRRI, Los Banos, Philippines.

Pandey PR, SP Pandey and YG Khadka. 1998. Long-term effect of organic and inorganic fertilizer on rice-wheat system in rainfed lowland condition of Khumaltar. In: Proceedings of first national workshop on long-term soil fertility experiments (SL Maskey, BP Tripathi, AP Regmi, JK Tuladhar and B Adhikary, eds). Soil Science Division, Nepal Agricultural Research Council, CIMMYT/HARP, Khumaltar, Nepal. Pp. 116-134.

Tripathi BP and BN Suwal. 1999. Effect of organic and inorganic fertilizers on rice and wheat yields and soil properties in rice-wheat system in rainfed lowland ecosystem. Nepal Ag. Res. Journal 3:89-93.

Yadav CR, RB Bhujel, HK Prasain and AL Chaudhary. 1998. Long-term fertility trail on rice-wheat-fallow cropping system at Tarahara. In: Proceedings of first national workshop on long-term soil fertility experiments (SL Maskey, BP Tripathi, AP Regmi, JK Tuladhar and B Adhikary, eds). Soil Science Division, Nepal Agricultural Research Council, CIMMYT/HARP, Khumaltar, Nepal. Pp. 35-58. 